УДК 340

DOI https://doi.org/10.32849/2663-5313/2020.5.34

\title{
Олександр Захарченко,
}

аспірант кафедри полічейського права

Національної академії внутрішніх справ

\section{ІСТОРІЯ СТАНОВЛЕННЯ ПРАВОВОГО РЕГУЛЮВАННЯ ІНСТИТУТУ ПІСЛЯДИПЛОМНОЇ ОСВІТИ ПОЛІЦЕЙСЬКИХ В УКРАЇНІ}

У статті наголошено, що в сучасних умовах функиіонування органів поліиії розвиток системи післядипломної освіти полічейських набуває найбільшої актуальності, адже підготовка висококваліфікованих фахівиів, здатних виконувати найскладніші правоохоронні функиії, є фундаментом для розвитку держави. Метою статті є визначення та характеристика основних етапів становлення та розвитку правового регулювання післядипломної освіти поліщейських в Україні. Розглянуто основні етапи становлення та розвитку правового регулювання післядипломної освіти поліцейських, починаючи із проголошення незалежності України. Підкреслено основні історичні етапи такого регулювання з урахуванням змін у структурі правоохоронних органів, переліку виконуваних функиій та нових викликів для суспільства. З'ясовано, що нормативно-правове регулювання післядипломної освіти і зміни щодо його особливостей необхідно проводити тільки за методами прогнозування, тобто передбачати тендениії розвитку суспільства, технологій, особливостей службової діяльності тощо. Наголошено, що існують галузеві нормативні документи, розроблені в процесі реформування системи $\mathrm{MBC}$, $i$, хоча вони прямо не встановлюють порядок отримання післядипломної освіти, однак їх сміливо можна віднести до однієї з ланок правового регулювання і розвитку структури післядипломної освітньої діяльності органів Начіональної полічії України.

Визначено, що видами службової підготовки є функиіональна підготовка, загальнопрофільна підготовка; тактична підготовка, вогнева підготовка, фізична підготовка. Службова підготовка здійснюється у формах навчальних занять у групах за місием служби; навчальних зборів; самостійного навчання. Зроблено висновок, що службова підготовка за змістом, формами та методами є аналогічною формам післядипломної освіти і покликана удосконалювати професійні навички та знання службовиів органів системи начіональної поліиї̈ України, як і післядипломна освіта. На наше переконання, ией відомчий нормативний акт також входить у систему післядипломної освіти та з'явився на етапі реформування та розвитку ивого правового галузевого інституту.

Ключові слова: правове регулювання, поліцейський, стажування, підвищення кваліфікації, перепідготовка, спеціалізація поліцейських.

Постановка проблеми. 3 проголошення у 1991 році незалежності України наша держава розпочала шлях побудови сучасної, самостійної, європейської, демократичної держави. Саме 3 цього часу і розпочинається процес створення та реформування всіх державних інститутів, які починають функціонувати у новоствореній державі. Відбувається трансформація моделі пострадянського державного управління у систему державних органів та установ, що покликані виконувати головні державні функції.

Вказані перетворення торкнулись і реформування системи профільної освіти, яка включала в себе весь процес підготовки кваліфікованих кадрів - від здобуття першої профільної вищої освіти до подальшого розвитку та вдосконалення знань індивідуума (підвищення кваліфікації, перепідготовки, післядипломної освіти тощо). 3 цього при- воду варто підкреслити, що окремим складником у системі підготовки кваліфікованих фахівців є підготовка поліцейських. У сучасних умовах функціонування органів поліції розвиток системи післядипломної освіти поліцейських набуває найбільшої актуальності, адже підготовка висококваліфікованих фахівців, здатних виконувати найскладніші правоохоронні функції, є фундаментом для розвитку держави.

Аналіз останніх досліджень i публікацій. Питання становлення та розвитку інституту післядипломної освіти в тому числі і в системі внутрішніх справ були предметом розгляду багатьох вчених, таких як: М. I. Ануфрієв, О. М. Бандурка, О. I. Безпалова, Ю. П. Битяк, О. С. Висоцька, І. П. Голосніченко, Т. І. Желудкова, І. Г. Кириченко, В. К. Колпаков, С. В. Курінний, Р. С. Мулукаєв, А. В. Перепелиця, Ю. М. Старилов, 
О. В. Філонов та інші. Поряд із цим вказані науковці лише фрагментарно досліджували теоретичні аспекти адміністративно-правового регулювання післядипломної освіти поліцейських.

Метою даної статті є визначення та характеристика основних етапів становлення та розвитку правового регулювання після॥ дипломної освіти поліцейських в Україні.

Виклад основного матеріалу. Можна сміливо стверджувати, що становлення інституту профільної післядипломної освіти в органах внутрішніх справ у нашій державі починається 3 проголошенням незалежност України. Саме в цей період створюються державні органи, які покликані виконувати безліч державних завдань, і суспільство зі свого боку висуває серйозні вимоги до функціонування державного апарату.

Як влучно зазначив М. I. Ануфрієв, на етапі розвитку суспільства виникла об'єктивна необхідність перегляду значної кількості існуючих до останнього часу уявлень про завдання, форми і методи національної освіти взагалі і відомчої системи підготовки персоналу органів внутрішніх справ зокрема. Це тим більш актуально, що курс на побудову демократичної, соціальної та правової держави Україна потребує критичного конструктивного аналізу досягнень і прорахунків освітянської системи у минулому та ï побудови на зовсім іншій, якісно досконалішій, методологічно-практичній основі [1, с. 16].

Першим реальним кроком становлення та розвитку правового регулювання інституту післядипломної освіти в Україні і післядипломної освіти поліцейських стало прийняття Закону України «Про освіту» від 23.05.1991 № 1060-XII (втратив чинність) [2]. Цей Закон вперше визначив мету освіти, якою встановив розвиток людини як особистості та найвищої цінності суспільства, розвиток іï талантів, розумових і фізичних здібностей, виховання високих моральних якостей, формування громадян, здатних до свідомого суспільного вибору, збагачення на цій основі інтелектуального, творчого, культурного потенціалу народу, підвищення освітнього рівня народу, забезпечення народного господарства кваліфікованими фахівцями. Крім того, у нормах цього Закону вперше у незалежній Україні післядипломну освіту було включено до системи освіти та надано тлумачення цього терміна. Так, стаття 47 згаданого Закону [2] визначала, що післядипломна освіта - це спеціалізоване вдосконалення освіти та професійної підготовки особи шляхом поглиблення, розширення та оновлення її знань, умінь і навичок на основі здобутої раніше вищої освіти (спеціальності) або професійно-технічної освіти (професії) та практичного досвіду. Крім того, положення ст. 47 Закону № 1060-XII передбачали, що післядипломна освіта включає: 1) спеціалізацію - профільну спеціалізовану підготовку з метою набуття особою здатності виконувати окремі завдання та обов'язки, що мають особливості в межах спеціальності; 2) перепідготовку - професійне навчання, спрямоване на оволодіння іншою професією працівниками, які здобули первинну професійну підготовку; 3) підвищення кваліфікації - підвищення рівня готовності особи до виконання їі професійних завдань та обов'язків або набуття особою здатності виконувати додаткові завдання та обов'язки шляхом набуття нових знань і вмінь у межах професійної діяльності або галузі знань; 4) стажування - набуття особою досвіду виконання завдань та обов'язків певної професійної діяльності або галузі знань. Також було передбачено перелік закладів, які належать до закладів післядипломної освіти, зокрема: академії, інститути (центри) підвищення кваліфікації, перепідготовки, вдосконалення, навчально-курсові комбінати; підрозділи вищих навчальних закладів (філіали, факультети, відділення та інші); професійнотехнічні навчальні заклади; науково-методичні центри професійно-технічної освіти.

Цей закон заклав фундамент функціонування та розвитку післядипломної освіти та став основою для розробки відомчих нормативних актів системи державного управління, спрямованих на розробку та впровадження моделей додаткової професійної підготовки фахівців. Не стала винятком і система органів внутрішніх справ. Так, норми Закону України «Про освіту» вперше знайшли своє відображення у відомчому Наказі МВС від 05.03.2013 № 219 «Про затвердження Положення про організацію післядипломної освіти працівників органів внутрішніх справ» (втратив чинність) [3], який став першим нормативним галузевим документом, що дав більш-менш чітку регламентацію процесу отримання післядипломної освіти працівників органів внутрішніх справ.

У цьому контексті варто зауважити, що, попри нагальність вирішення питання підвищення професійного рівня міліціонерів, профільний Закон України «Про міліцію» не містив норм, які встановлювали особливості отримання додаткової освіти та професійних знань і навичок для працівників системи органів внутрішніх справ.

3 цього приводу повністю погоджуємося з I. Г. Кириченко, який у своєму науковому 
дослідженні зазначив, що створення розгалуженої відомчої багатоступеневої системи підготовки кадрів для органів внутрішніх справ викликане не якимось надуманими, штучними факторами, а сучасними соціально-економічними умовами розвитку державності та громадянського суспільства. Так, система підготовки висококваліфікованого персоналу, яка існувала в колишньому СРСР та в перші роки незалежності держави, недостатньою мірою відповідала своєму призначенню. Донедавна в Україні не було профілізованих вищих навчальних закладів 3 підготовки спеціалістів для таких провідних служб, як слідство і дізнання, захист економіки від злочинних посягань, експертно-кримінальна, дорожня автоінспекція, державна служба охорони, та багатьох інших. Щорічно Міністерство внутрішніх справ України отримувало близько двох з половиною тисяч фахівців юридичного профілю 3 навчальних закладів системи МВС СРСР, але фахівців з вищою кваліфікацією - переважно з тих, що були дипломовані за межами України [4, с. 3].

32013 року поступово почалось становлення нормативно-регуляторного підгрунтя післядипломної освіти системи органів внутрішніх справ. Так, вищезгадане Положення про організацію післядипломної освіти працівників органів внутрішніх справ передбачило 4 складника післядипломної освіти, а саме: перепідготовку; спеціалізацію; підвищення кваліфікації; стажування. Крім того, це Положення вперше регламентувало основні завдання післядипломної освіти працівників органів внутрішніх справ, а саме: оволодіння необхідними знаннями і спеціальними навичками для успішного виконання обов'язків 3 охорони громадського порядку і боротьби зі злочинністю та інших оперативно-службових завдань; удосконалення навичок управлінської діяльності, опанування методик навчання та виховання підлеглих, упровадження в практичну діяльність досягнень науки, передових форм і методів роботи, основ наукової організації праці; формування професійної самосвідомості працівників, почуття відповідальності за свої дії, розуміння необхідності постійного вдосконалення своєї професійної майстерності з урахуванням специфіки діяльності в конкретних підрозділах органів внутрішніх справ; навчання працівників прийомам та засобам забезпечення особистої безпеки при виконанні службових обов'язків, під час надзвичайних подій і в екстремальних умовах; удосконалення навичок працівників поводження зі спеціальними засобами і спеціальною технікою, експлуатації тран- спортних засобів, засобів зв'язку; зміцнення зв'язків із населенням, дотримання працівниками міліції прав людини та громадянина під час виконання ними службових обов'язків, підвищення рівня загальної культури; формування високої психологічної стійкості працівників, розвиток у них спостережливості, пильності, пам'яті, мислення й інших професійно-психологічних якостей і навичок.

Саме в цей період було також розроблено Положення з організації стажування керівного і педагогічного складу училищ професійної підготовки працівників міліції та навчальних центрів підготовки працівників органів внутрішніх справ у вищих навчальних закладах МВС України, яке затверджено Наказом МВС України від 12.08.2013 № 773 [5]. Це Положення врегулювало порядок стажування керівного і педагогічного складу училищ професійної підготовки працівників міліції та навчальних центрів підготовки працівників органів внутрішніх справ у вищих навчальних закладах МВС України та оформлення його результатів, вперше визначило значення та зміст терміна «стажист» та основні функції керівників стажування службовців.

Таким чином, на той час із чотирьох складників післядипломної освіти законодавче врегулювання отримав лише такий вид післядипломної освіти, як стажування.

Значний вплив на розвиток та становлення правового регулювання системи післядипломної освіти поліцейських в Україні здійснила Національна стратегія розвитку освіти в Україні на період до 2021 року, яку було схвалено Указом Президента України від 25.06.2013 № 344/2013 [6].

Початком же системних змін у структурі, функціях та завданнях органів внутрішніх справ є прийняття Верховною Радою України Закону України «Про Національну поліцію» від 02.07.2015 № 580-VIII [7] та Постанови Кабінету Міністрів України «Про утворення Національної поліції України» від 02.09.2015 № 641 [8].

Ці законодавчі акти започаткували функціонування принципово нового органу державної виконавчої влади та встановили основні напрями діяльності системи органів внутрішніх справ. Важливо, що вже в новому профільному законі відбулось нормативне закріплення особливостей отримання післядипломної освіти поліцейськими. Так, стаття 75 Закону України «Про Національну поліцію» передбачила, що післядипломна освіта поліцейських здійснюється на загальних засадах, визначених Законом України «Про вищу освіту» від 01.07.2014 № 1556-VII, 
3 урахуванням особливостей, визначених цим Законом, і складається з: 1) спеціалізації; 2) перепідготовки; 3) підвищення кваліфікації; 4) стажування. Таким чином, на цьому історичному етапі у спеціальному профільному Законі були закріплені види післядипломної освіти поліцейських, які до цього містились лише у Законі України «Про освіту» від 23.05.1991 № № 1060-XII [2].

Разом із прийняттям профільного Закону розроблено та прийнято нове Положення про організацію післядипломної освіти працівників Національної поліції, яке затверджено наказом Міністерства внутрішніх справ України від 24.12.2015 № 1625 [9]. Це Положення визначає організаційно-правові засади організації післядипломної освіти працівників Національної поліції України, що проходять службу (працюють) на посадах, які за класифікацією професій належать до категорій керівників, професіоналів, фахівців та робітничих кадрів.

Тож першим реальним кроком на шляху реформування та становлення інституту післядипломної освіти поліцейських було встановлення норм щодо її отримання службовцями саме у профільному Законі. 3 нашого погляду, саме таке законодавче закріплення «функціонування» інституту післядипломної освіти поліцейських і стало ключовим етапом переходу від пострадянської застарілої моделі підготовки та перепідготовки службовців до впровадження нових форм та методів цього інституту. Важливо, що такого оновлення потребувало і суспільство, яке і сьогодні висуває дуже серозні вимоги до правоохоронців, до їх особистості, професійних умінь, знань та навичок, особистих здобутків.

Як слушно свого часу вказала О. Є. Висоцька, становлення України як правової, демократичної, соціальної та європейської держави має конституційний характер. Тому «сьогодні головним виміром освітньої діяльності має бути формування особистості, яка здатна повноцінно жити й активно діяти у новому світі, постійно самовдосконалюватися, адекватно реагувати на зміни в умовах глобалізації та інформаційно-технологічної революції. Йдеться про зміни технологій, інформації, знань, самих обставин життя. Саме тому сучасна освіта повинна мати випереджувальний характер, тобто бути націленою на майбутнє, на розв'язання проблем нового століття, розвиток ключових компетенцій особистості, формування в неї нової культури, нових способів мислення та діяльності» $[10$, с. 6$]$.

Ми повністю погоджуємось із науковцем і вважаємо, що нормативно-правове регулювання післядипломної освіти і зміни щодо його особливостей необхідно проводити тільки методами прогнозування, тобто передбачати тенденції розвитку суспільства, технологій, особливостей службової діяльності тощо.

На продовження нашого наукового дослідження варто зазначити, що існують і деякі галузеві нормативні документи, розроблені в процесі реформування системи МВС, і хоча вони прямо не встановлюють порядок отримання післядипломної освіти, однак їх сміливо можна віднести до однієї з ланок правового регулювання і розвитку структури післядипломної освітньої діяльності органів Національної поліції України.

Таким нормативним документом є Положення про організацію службової підготовки працівників Національної поліції України, яке затверджено Наказом Міністерства внутрішніх справ України від 26.01.2016 № 50 [11].

Це положення передбачає та встановлює порядок планування, проведення та обліку занять, здійснення контролю знань, умінь та навичок осіб молодшого, середнього та вищого складу Національної поліції України. Крім того, воно визначає і основні завдання службової підготовки, які полягають у: підвищенні рівня знань, умінь, навичок та професійних якостей поліцейських з метою забезпечення їхної здатності до виконання завдань з охорони прав і свобод людини, протидії злочинності, підтримання публічного (громадського) порядку та безпеки; вивченні нормативно-правових актів, які регламентують діяльність Національної поліції України; удосконаленні керівним складом органів (закладів, установ) поліції навичок управління поліцейськими. Видами службової підготовки є функціональна підготовка, загальнопрофільна підготовка; тактична підготовка, вогнева підготовка, фізична підготовка. Службова підготовка здійснюється у формах навчальних занять у групах за місцем служби; навчальних зборів; самостійного навчання (проводиться впродовж усього строку служби поліцейського з метою безперервного, систематичного поповнення та поглиблення знань, умінь і навичок, необхідних для успішного виконання службових завдань).

\section{Висновки}

Таким чином, є очевидним, що службова підготовка за змістом, формами та методами $є$ аналогічною формам післядипломної освіти і покликана удосконалювати професійні навички та знання службовців органів системи національної поліції України, як i післядипломна освіта. На наше переконання, цей відомчий нормативний акт також входить у систему післядипломної освіти 
та з'явився на етапі реформування і розвитку цього правового галузевого інституту.

У контексті розгляду запропонованої тематики проведене дослідження дозволяе нам виділити і охарактеризувати основні етапи становлення та розвитку правового регулювання післядипломної освіти поліцейських в незалежній Україні, а саме:

I етап. 1991-2015 pp. Після проголошення незалежності в Україні відбувається ряд реформ, приймається Закон України «Про освіту», який законодавчо закріплює визначення терміна «післядипломна освіта» та окреслює іiї основні завдання. У 2013 році розробляється та затверджується перше профільне Положення Про організацію післядипломної освіти працівників органів внутрішніх справ, яке регламентує основні завдання післядипломної освіти працівників органів внутрішніх справ. Особливістю цього етапу є те, що в цей період було відсутне законодавче закріплення особливостей здобуття післядипломної освіти в системі органів внутрішніх справ на рівні профільного закону «Про міліцію».

II етап: 2015-2019 рр. Створення Національної поліції України. Закріплення видів та основних завдань післядипломної освіти поліцейських на рівні профільного Закону України «Про Національну поліцію», затвердження нового Положення про організацію післядипломної освіти працівників Національної поліції. У цей період відбувається стрімкий розвиток всіх видів післядипломної освіти поліцейських, впроваджуються нові методи та способи підготовки, перепідготовки та підвищення кваліфікації службовців, розроблено чіткий механізм проходження поліцейськими стажування як одного із видів післядипломної освіти. Впроваджуються сучасні технології у процес освіти, проводиться комплексний методологічний супровід післядипломної освіти, пріоритетність надається спеціалізації службової підготовки залежно від виду виконуваних функцій та завдань окремих підрозділів поліції (патрульні, слідчі, спецпризначенці тощо).

\section{Список використаних джерел:}

1. Ануфрієв M.I. Становлення, розвиток та основні напрямки удосконалення відомчої бага- тоступеневої системи підготовки персоналу ОВС. Вісник Харківського наиіонального університету внутрішніх справ : збірник наукових праць. 1999. Випуск 9. С. 16-20.

2. Про освіту : Закон України від 23.05.1991 № № 1060-XII. Відомості Верховної Ради УРСР. 1991. № 34. Ст. 451.

3. Положення Про організацію післядипломної освіти працівників органів внутрішніх справ : Наказ МВС України від 05.03.2013 № 219. Офiиійний вісник України. 2013. № 28. Ст. 318. Ст. 982 код акта 66659/2013.

4. Кириченко І.Г. Підготовку кадрів для органів внутрішніх справ України на рівень вимог сьогодення. Іиформаиійний бюлетень РНМЦ УАВС. 1995. № 4.

5. Положення з організації стажування керівного і педагогічного складу училищ професійної підготовки працівників міліції та навчальних центрів підготовки працівників органів внутрішніх справ у вищих навчальних закладах МВС України : Наказ МВС України від 12.08.2013 № 773. Oфiиійний вісник України. 2013. № 71. Ст. 81. Ст. 2626 , код акта 68729/2013.

6. Національна стратегія розвитку освіти в Україні на період до 2021 року : Указ Президента України від 25.06.2013 № 344/2013. Офімійний вісник України. 2013. № 50. Ст. 18. Ст. 1783, код акта $67681 / 2013$.

7. Про Національну поліцію : Закон України від 02.07.2015 № 580-VIII. Відомості Верховноі Ради України. 2015. № 40-41. С. 1970. Ст. 379.

8. Про утворення Національної поліції України : Постанова Кабінету Міністрів України від 02.09.2015 № 641. Офіиійний вісник Украӥни. 2015. № 72. С. 61. Ст. 2363, код акта 78422/2015.

9. Положення про організацію післядипломної освіти працівників Національної поліції : Наказ Міністерства внутрішніх справ України від 24.12.2015 № 1625. Офімійний вісник України. 2016. № 11. С. 173. Ст. 485, код акта $80657 / 2016$.

10. Висоцька О.Є. Філософсько-світоглядні та методологічні засади випереджаючої освіти для сталого розвитку. Випереджаюча освіта для сталого розвитку як практично-зорієнтована модель реформування галузі в регіоні : матеріали Всеукр. наук.-практ. конф. (м. Дніпропетровськ, 31 березня 2011 р.) Дніпропетровськ: ДОІППО, 2011. С. 6-10.

11. Положення про організацію службової підготовки працівників Національної поліції України : Наказ Міністерства внутрішніх справ України від 26.01.2016 № 50. Офіиійний вісник України. 2016. № 22. С. 42. Ст. 861, код акта $81130 / 2016$

The article emphasizes that in the current conditions of functioning of police bodies, the development of the system of postgraduate education of police officers is gaining topical importance, since the training of highly qualified specialists capable of performing the most complex law enforcement functions is the foundation for the development of the state. Thus, the purpose of the article is to identify and characterize the main stages of formation and development of legal regulation of postgraduate police education in Ukraine. The basic stages of formation and development of legal regulation of police postgraduate education have been considered since the declaration of independence of Ukraine. The main historical stages of such regulation are emphasized, taking into account changes in the structure of law enforcement agencies, the list 
of performed functions and new challenges of society. It has been found out that the normative legal regulation of postgraduate education and changes to its peculiarities should be made only according to forecasting methods, that is, to predict tendencies of development of society, technologies, peculiarities of professional activity, etc. It is emphasized that there are sectoral normative documents developed in the process of reforming the Ministry of Internal Affairs, which, although they do not directly establish the procedure for obtaining postgraduate education, but can be safely attributed to one of the links of legal regulation and development of the structure of postgraduate educational activities of the National Police of Ukraine. It is determined that the types of job training are functional training, general training; tactical training, fire training, physical training. The training is carried out in the following forms: training sessions in groups at the place of service; training fees; self-study. It is concluded that professional training in content, forms and methods is analogous to the forms of postgraduate education and aims to improve the professional skills and knowledge of officials of the bodies of the national police system of Ukraine, as well as postgraduate education. In our opinion, this departmental normative act is also included in the system of postgraduate education and appeared at the stage of reforming and development of this legal sectoral institute.

Key words: legal regulation, police officer, internship, advanced training, retraining, police specialization. 